\title{
G Protein-Coupled Estrogen Receptor Is a Critical Regulator in Metastasis of Breast Cancer Cells
}

\author{
Bin Gao1, Ping Chen1, Qifeng Jiang2 ${ }^{*}$ \\ ${ }^{1}$ Department of Medical Information, Chongqing Medical University, Chongqing, China \\ ${ }^{2}$ Department of Biochemistry and Molecular Biology, Chongqing Medical University, Chongqing, China \\ Email: *jqf1008@aliyun.com
}

How to cite this paper: Gao, B., Chen, P. and Jiang, Q.F. (2017) G Protein-Coupled Estrogen Receptor Is a Critical Regulator in Metastasis of Breast Cancer Cells. Journal of Biosciences and Medicines, 5, 127-140. https://doi.org/10.4236/jbm.2017.58010

Received: July 18, 2017

Accepted: August 21, 2017

Published: August 24, 2017

Copyright $\odot 2017$ by authors and Scientific Research Publishing Inc. This work is licensed under the Creative Commons Attribution International License (CC BY 4.0).

http://creativecommons.org/licenses/by/4.0/ c) (i) Open Access

\begin{abstract}
Estrogen signaling via GPER in breast cancers has been intensively discussed over years, but the underlying molecular mechanism remains to be fully elucidated, especially for the transcriptional profiles of the GPER under estrogen stimulation. In this study, we evaluated the potential role GPER in regulating invasion of metastatic breast cancer cell line MDA-MB-231 via transcriptional way. First, with primary breast cancer tissue samples, we found that the expression of GPER significantly coordinated with another membrane receptor-CXCR1. Besides, the expression level of these two proteins was associated with the development of the primary breast cancers. Second, to dissect the cross talk between GPER and CXCR1, we further our studies to detect the activation of ERK, Akt and transcriptional factor NF-kB. We found that upon estrogen stimulation, the phosphorylation level of ERK and Akt were rapidly increased and then resulted in the activation and nucleus translocation of NF-kB. When we considered the sub-sequence of the NF-kB activation, we found the autocrine of IL- 8 was boosted by stimulation of the estrogen and followed by the promoted invasion of the MDA-MB-231 cells. In conclusion, our data demonstrated the estrogen-mediated GPER stimulation would regulate the invasive activities of metastatic breast cancer cell line MDA-MB-231 coupled with another membrane receptor CXCR1 via transcriptional pathway, the cross talk between GPER and CXCR1 may be another target for breast cancer therapies.
\end{abstract}

\section{Keywords}

GPER, Metastasis, Breast Cancer, CXCR1 


\section{Introduction}

The growth of $40 \%-70 \%$ breast cancer is related to the estrogen [1]. By binding to the estrogen receptor (ER), estrogen modulates the expression of downstream genes and regulates the growth and differentiation of many normal and neoplastic tissues including breast, endometrial and ovarian tumors [2] [3]. In addition to its ability to mediate gene transcription, estrogen also elicits rapid, non-transcriptional effects involving activation of signal transducing pathways including activation of extracellular signal-regulated kinase (ERK) and phosphatidylinositol 3-kinase (PI3K)/Akt signaling in normal and cancer cells [4] [5].

It's been established that estrogen mediates rapid signaling events via pathways that involve transmembrane ERs, such as G-protein-coupled ER 1 (GPER) [6] [7]. GPER has been recently shown to mediate estrogen signaling in a variety of normal and cancer cell types [8] [9] [10] [11]. In particularly, GPER has been involved in rapid events induced by estrogens, including the transactivation of epidermal growth factor receptor, the activation of the mitogen-activated protein kinase (MAPK) and (PI3K)/Akt transduction pathways, the stimulation of adenylylcyclase and the mobilization of intracellular calcium [10] [12] [13]. It has been suggested that tumor cells produce IL-8 as an autocrine growth factor, which promotes tumor growth, tissue invasion and metastasis [14] [15] [16]. Moreover, IL-8 expression is considered to be associated with a higher invasiveness potential of ER-negative breast cancer cells in vitro, which suggests that IL- 8 could be a novel marker of breast cancer aggressiveness [17]. The biological effects of IL-8 are mediated through the binding of IL-8 to two cell-surface G protein-coupled receptors, termed CXCR1 and CXCR2 [18] [19], but the detailed signaling pathway for IL-8 and its two receptors are not quite clear at present. The recent studies showed that CXCR1 blockade would significantly inhibit the proliferation and metastasis of breast cancer stem cells [20] and this result suggested that IL-8/CXCR1 would be a key signaling pathway for breast cancer cells. Since it has been reported that IL-8 levels are modulated by NF-kB which is an important transcriptional factor in estrogen-GPER signaling pathway [21] [22], it's quite reasonable for us to imagine the activation of GPER may stimulate the ERK or Akt cascades and then promote the autocrine of IL-8 in breast cancer cells. The accumulation of IL- 8 may directly activate CXCR1 resulting in enhanced invasion activities.

To provide evidences for our hypothesis, in this study, we investigated the possible role of GPER in breast cancer cell invasion upon estrogen stimulation. First, the expression level of GPER and CXCR1 were checked with different stage of primary breast cancer tissue samples followed by determination of expression level of GPER and CXCR1 expression in metastatic and non-metastatic breast cancer cell lines; Second, the effect of estrogen on ERK/Akt cascades activation and its relationship with NF-kB/IL-8 pathways were investigated; Furthermore, the invasive activities of breast cancer cells were determined upon estrogen stimulation via IL-8/CXCR1 signaling pathway. Our results indicated that 
the activation of GPER by estrogen may trigger the ERK/Akt cascades resulting in the increased expression of IL-8 promoted by NF-kB, ultimately enhance the invasive activities of breast cancer cells via IL-8/CXCR1 signaling pathway.

\section{Material and Methods}

\subsection{Tissue Samples and Clinicopathological Data}

Total 39 human breast cancer tissue samples were obtained from Second Affiliated Hospital of Chongqing Medical University. All patients were underwent surgery at Second Affiliated Hospital of Chongqing Medical University during 2008-2011 and all tissue samples were identified as breast cancer by clinicopathological diagnose and divided into three groups by TNM standard: 3 for stage I, 27 for stage II and 9 for stage III. Patients were informed before all experiments with ethical approval.

\subsection{Immunohistochemical Staining}

All tissue samples were fixed with formalin and embedded in paraffin. Immunohistochemical staining with streptavidin-peroxidase assay was conducted as manufacturer instructions (Minneapolis, MN). Briefly, $4 \mu \mathrm{m}$ thick tissues sections were deparaffinized, heated at $95^{\circ} \mathrm{C}$ sodium citrate for antigen retrieval, and the endogenous peroxidase activity was quenched by $3 \% \mathrm{H}_{2} \mathrm{O}_{2}$. Nonspecific binding sites were blocked by goat serum. Slides were exposed to Rabbit anti-GPER polyclonal antibody (Abcam) and Rabbit anti-CXCR1 polyclonal antibody (Abcam) with 1:250 dilution or PBS as negative control for $2 \mathrm{~h}$ at $25^{\circ} \mathrm{C}$. Sections were incubated with horseradish peroxidase-conjugated goat anti-rabbit IgG (Hyclone) for 20 minutes at $37^{\circ} \mathrm{C}$ to detect tissue-associated rabbit antibodies. Nuclei were counterstained with hematoxylin. Reduction mammoplasty tissue was used as positive control.

\subsection{Evaluation of Immunohistochemical Staining Pattern}

Evaluation of immunohistochemical staining was processed by semiquantitative method under phase-contrast microscopy system. Briefly, five 400X yields were randomly chosen from every specimen, 100 cells were counted for each yield and the positive staining was identified by yellow or brown staining of nuclei, cytoplasm or membrane. Staining scores were consisted by two parts. The staining proportion scores: 0 , negative staining in all cells; $1, \leq 25 \%$ cells stained; $2,26 \% \sim$ $50 \%$ cells stained; $3,51 \% \sim 75 \%$ cells stained; $4,>75 \%$ cells stained. The staining intensity scores: 0 , negative staining; 1 , light yellow; 2, yellow; 3, brown. Adding two parts of scores as the staining scores: $0,(-) ; 2-3,( \pm) ; 4-5,(+) ; 6-7,(++)$. $(+)$ and $(++)$ were considered as positive staining.

\subsection{Cell Culture}

Human breast cancer cell lines MDA-MB-231 and MCF-7 were maintained in RPMI1640 (GIBCO) supplemented with 10\% fetal bovine serum (GIBCO) and 
$1 \%$ antibiotics (Penicillin-Streptomycin, GIBCO). Cells were cultured at $37^{\circ} \mathrm{C}$ under a $5 \% \mathrm{CO}_{2}$ atmosphere and all experiments were conducted with $\log$ phase cells.

\subsection{Western-Blotting Analysis}

The expression level of total GPER, CXCR1, ER, Akt (tAkt), phosphorylation Akt (pAkt), total ERK (tERK), phosphorylation ERK (pERK) and NF-kB (p65) were evaluated by western-blotting analysis using Quantity one system. MDAMB-231 cells were treated with $10^{-8} \mathrm{~mol} / \mathrm{L}$ E2 and proteins were extracted after different time course. Total cell extracts were separated on SDS-PAGE and immunoblotted with rabbit anti-GPER, CXCR1, ER, tAkt, -pAkt, -tERK, -pERK, -p65 polyclonal antibodies (Abcam), followed by anti-rabbit secondary antibodies conjugated with horseradish peroxidase (Hyclone) respectively. For p65, the MDA-MB-231 cells were treated with $10^{-8} \mathrm{~mol} / \mathrm{L}$ E2 alone or combination with $2 \mu \mathrm{M}$ lycopene and incubated for $4 \mathrm{~h}$ before the cells harvested for lysis. The digitized fluorescent bands were integrated by ECL and normalized against the amount of $\beta$-actin, which was used as a loading reference.

\subsection{ELISA Analysis}

The expression level of IL-8 in MDA-MB-231 cells was evaluated by ELISA analysis (Minneapolis, MN). MDA-MB-231 cells were treated with $10^{-8} \mathrm{~mol} / \mathrm{L}$ E2 for $1-24 \mathrm{~h}$ and the supernates were collected for ELISA analysis. The measurements were according to manufacturer instructions. Briefly, $50 \mu \mathrm{l}$ of Standard, blank control and sample were added for each well, incubated at $37^{\circ} \mathrm{C}$ for $0.5 \mathrm{~h}$ and wash. $50 \mu \mathrm{lL}-8$ Conjugates were added for all wells and incubated at $37^{\circ} \mathrm{C}$ for $0.5 \mathrm{~h}$ followed by adding $100 \mu \mathrm{l}$ Substrate Solution after wash with 10 min incubation at $37^{\circ} \mathrm{C} .50 \mu \mathrm{l}$ stop solution was added to each well and optical density of each well was determined with microplate reader at $450 \mathrm{~nm}$ using blank well as reference.

\subsection{Cell Invasion Assay}

Cell invasion was assayed with 24-well cell invasion Transwell assay plates comprising a polycarbonate membrane with $8-\mu \mathrm{m}$ pores (BD). The inner and outer chamber membranes were coated with $5 \mu \mathrm{g} / \mathrm{ml}$ of human fibronectin (R\&D) at $37{ }^{\circ} \mathrm{C}$ for $2 \mathrm{~h}$, and then rinsed with PBS. MDA-MB-231 cells were treated with $\mathrm{E} 2$ for $8 \mathrm{~h}$ before seeding on the inner chamber of the Transwell plate at a concentration of $1 \times 10^{6}$ cells $/ \mathrm{ml}$ in $200 \mu \mathrm{l}$ serum-free RPMI1640. The outer chamber was filled with $800 \mu$ f full culture medium which contained 10\% FBS and incubated for $48 \mathrm{~h}$ at $37^{\circ} \mathrm{C}$. The number of invaded cells was counted in fields randomly chosen from 5 equally divided zones of the membrane in triplicates under phase-contrast and fluorescence channel with the phase-contrast microscope system.

\subsection{Statistical Analysis}

The SPSS version 17.0 for Windows (SPSS Inc., Chicago, USA) was used for the 
statistical analysis. All measurements are expressed in terms of mean \pm standard deviation $(\bar{x} \pm s)$. Comparisons between 2 samples of unequal variance were performed by the $\chi^{2}$ test, the Spearman test and individual sample $t$ test. P-values of 0.05 or less were considered to be statistically significant.

\section{Results}

\subsection{GPER and CXCR1 Staining Patterns in Breast Cancer Tissues and Cells}

The predominant staining patterns of GPER and CXCR1 were cytoplasmic in carcinoma tissues regardless of the histopathological type (Figure 1). No nuclear staining was observed. GPER was positive in $68.9 \%$ of all specimens in which CXCR1 was $71.7 \%$, revealing the extensive expression of GPER and CXCR1 in primary breast carcinomas (Table 1). The association between GPER and CXCR1 was significant ( $\mathrm{p}=0.04)$, whereas $96 \%$ of the CXCR $1+$ specimens were positive for GPER, implying the expression of GPER may be consistent with CXCR1. Furthermore, the expression level of GPER and CXCR1 were significantly associated with the developing stage of the breast cancer tissues, the stage I showed relatively low staining of GPER and CXCR1 which significantly increased in stage II. The stage III tissues exhibited much higher GPER and CXCR1 expression than stage I and II which means GPER and CXCR1 expression level may have positive relationship with the malignity of breast cancer (Figure 1).

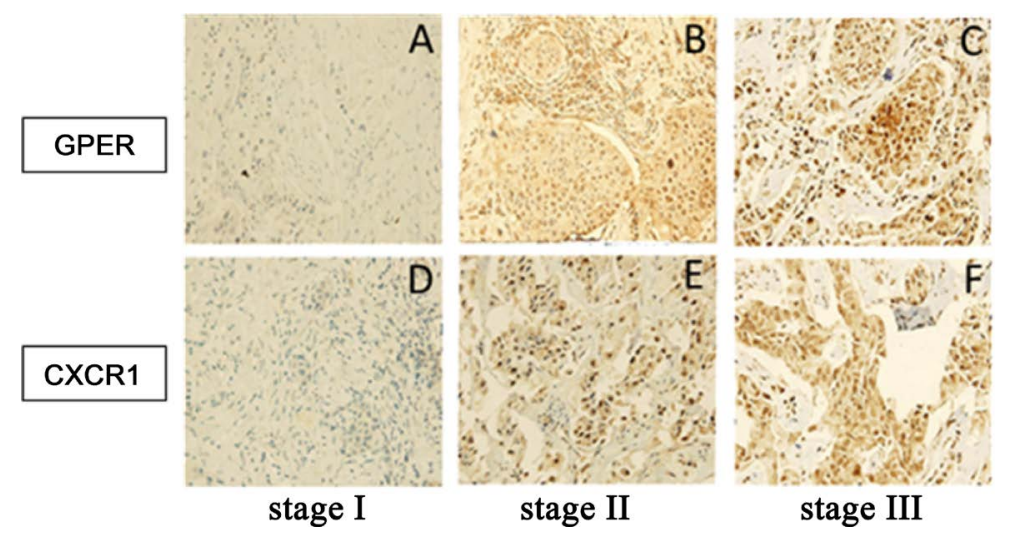

Figure 1. The immunohistochemical stainings of GPER and CXCR1 in breast cancer tissues (x100). A-C were immunohistochemical staining of GPER from stage I to III: the expression level of GPER was increased with the developing stage of breast cancer and stage III tissues exhibited highest expression of GPER; D-F were immunohistochemical staining of CXCR1 from stage I to III: the expression level of CXCR1 was increased with the developing stage of breast cancer and stage III tissues exhibited highest expression of CXCR1.

Table 1. Expression of GPER and CXCR1 with clinicopathological factors.

\begin{tabular}{ccccc}
\hline Tissue samples & GPER+ & GPER- & CXCR1+ & CXCR1- \\
\hline 39 & 27 & 12 & 28 & 11 \\
\hline
\end{tabular}




\subsection{The Comparison of GPER, CXCR1 and Estrogen Nuclear Receptors Expression between Metastatic and Non-Metastatic Breast Cancer Cells}

In order to distinguish the different expression level of GPER, CXCR1 and estrogen nuclear receptors in metastatic and non-metastatic breast cancer cells, MDA-MB-231 and MCF-7 were chosen for western-blotting analysis (Figure 2). Results showed that the expression level of estrogen receptors $\operatorname{ER} \alpha$ and $\operatorname{ER} \beta$ were almost undetectable in MDA-MB-231 cells whereas MCF-7 cells had significant high expression (Figure 2(A)). Compared to the expression level of $\beta$-actin, the relative expression amounts in MCF-7 were 4 folds for ER $\alpha$ and 18 folds for ER $\beta$ to MDA-MB-231 respectively (Figure 2(B)). The MDA-MB-231 and MCF-7 cells had very similar expression level of GPER and the difference was not significant. But, interestingly, the CXCR1 expression level was much stronger in MDA-MB-231 than MCF-7 cells and the relative expression level of CXCR1 was nearly 3 folds in MDA-MB-231 to MCF-7 cells (Figure 2(B)). As a kind of metastatic breast cancer cell line, MDA-MB-231 cells naturally had stronger migration and invasion activities than MCF-7 cells despite the lower $\operatorname{ER} \alpha, \operatorname{ER} \beta$ and similar GPER expression, the difference in CXCR1 expression level may play a important role to determine the malignance in MDA-MB-231 and MCF-7 cells and this different malignance was independent from the expression level of estrogen receptors $\mathrm{ER} \alpha$ and $\mathrm{ER} \beta$.

\subsection{Effect of Estrogen on Activation of Akt and ERK}

Signaling through GPER by estrogen stimulation occurs via transactivation of the epidermal growth factor receptor (EGFR) [23] [24]. In order to probe such

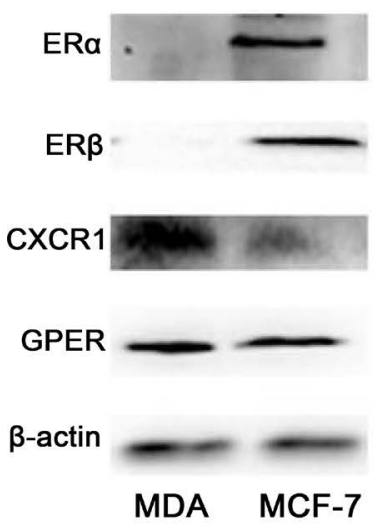

(A)

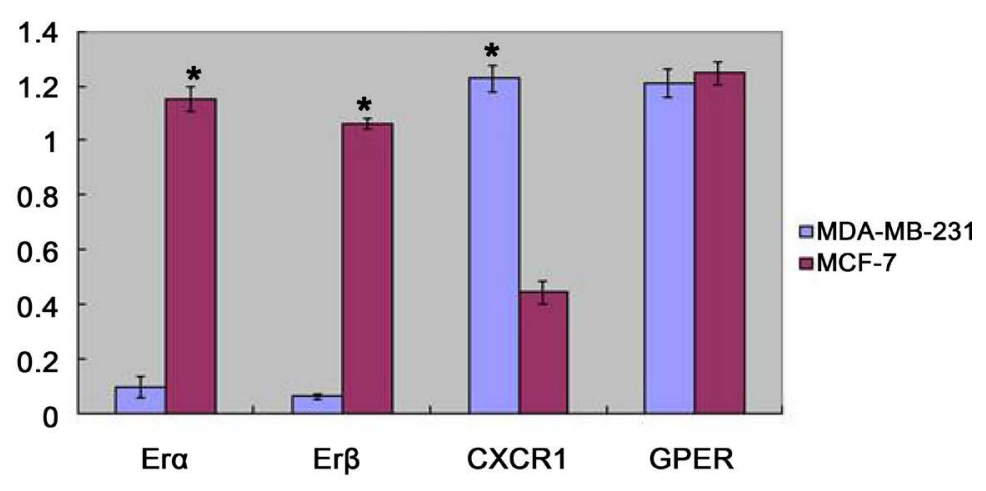

(B)

Figure 2. The expression levels of ER $\alpha, \mathrm{ER} \beta$, GPER and CXCR1 in MDA-MB-231 and MCF-7 cells. The signals of $\operatorname{ER} \alpha, \operatorname{ER} \beta$, GPER and CXCR1were quantified to the $\beta$-actin after measurement of the optical density of the protein bands, and the relative expression amounts of ER $\alpha$, ER $\beta$, GPER and CXCR1 are shown in the bar diagram. Data represent a mean of three independent experiments ${ }^{*} \mathrm{p}<0.05$. (A) The expression of $\mathrm{ER} \alpha, \mathrm{ER} \beta$, GPER and CXCR1 in MDA-MB-231 and MCF-7 cells, $\beta$-actin as reference; (B) The relative expression level of $\operatorname{ER} \alpha, \mathrm{ER} \beta$, GPER and CXCR1 after quantified to $\beta$-actin: $\mathrm{ER} \alpha$ and $\mathrm{ER} \beta$ expression were much lower in MDA-MB-231 than MCF-7 cells; Both cell line had similar expression in GPER but the expression level of CXCR1 was much stronger in MDA-MB-231 than MCF-7 cells. 




(A)

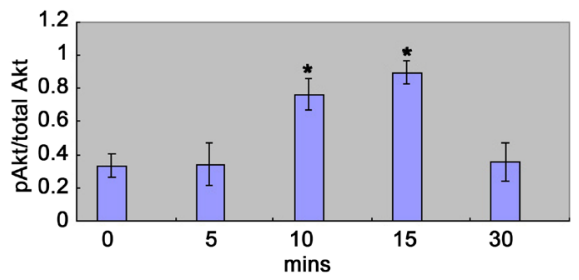

(B)

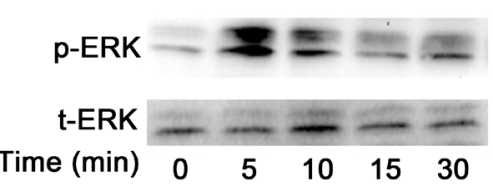

(C)

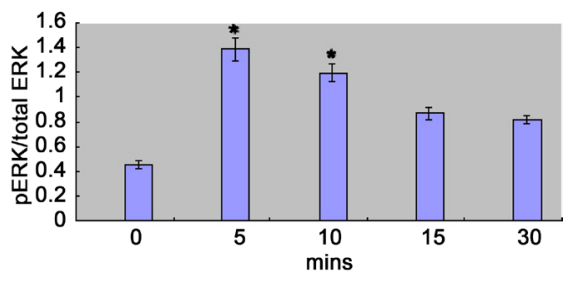

(D)

Figure 3. Effect of estrogen on activation of Akt and ERK in time course. MDA-MB-231 cells were treated with $10^{-8} \mathrm{~mol} / \mathrm{L}$ E2 and incubated for different durations of time before the cells harvested for lysis. The signals of p-protein and total protein were quantified after measurement of the optical density of the protein bands, and the ratios of p-proteins/t-proteins are shown in the bar diagram. Data represent a mean of three independent experiments ${ }^{*} \mathrm{p}<0.05$. (A) expression of $\mathrm{p}$-Akt and total Akt in MDA-MB-231 cells; (B) bar diagram of the ratios of p-Akt/total Akt in the MDA-MB-231 cells in time course; (C) expression of p-ERK and total ERK in MDA-MB-231 cells; (D) bar diagram of the ratios of p-ERK/total ERK in the MDA-MB-231 cells in time course.

regulation and dissect the possible signaling pathway, we examined Akt and ERK activation in MDA-MB-231 cells in response to treatment with estrogen. Akt and ERK activation stimulated by $10^{-8} \mathrm{~mol} / \mathrm{L}$ E2 after exposure at different lengths of time were investigated in MDA-MB-231 cells. The ratio of phosphorylation proteins/total proteins was used as levels of activation of Akt and ERK. Result showed that a rapid activation of Akt was observed by this concentration of E2 within 15 mins, estrogen induced a significant increase of Akt phosphorylation and the peak level of p-Akt could be observed at $15 \mathrm{~min}$ in MDA-MB-231 cells (Figure 3); The activation of ERK by estrogen was even faster than Akt, the peak level of p-ERK appeared at $5 \mathrm{~min}$.

\subsection{The Activation and Nuclear Translocation of NF-kB upon Estrogen Stimulation}

$\mathrm{NF}-\mathrm{kB}$ is one of the redox-sensitive transcription factors. Upon stimulation, activated NF-kB will translocate to the nucleus and bind to promoters of its target genes and regulates the expression of genes involved in many cellular events including proliferation and migration through the activation of the Akt and ERK cascades [25] [26] [27] [28]. To elucidate whether the activation of GPER by estrogen affected activation and nuclear translocation of NF-kB through Akt and ERK cascades, NF-kB (p65)-associated proteins in cytoplasma and nucleus were measured in MDA-MB-231 cells upon estrogen stimulation by western-blotting. We analyzed the effects of $\mathrm{E} 2$ alone and in combination with lycopene, on total NF-kB expression level in MDA-MB-231 cells. As shown in Figure 4, a 4 h-treatment of the MDA-MB-231 cells with $10^{-8} \mathrm{~mol} / \mathrm{L}$ E2 resulted in an increase 
NF-kB (p65)

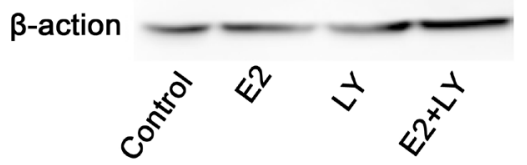

(A)

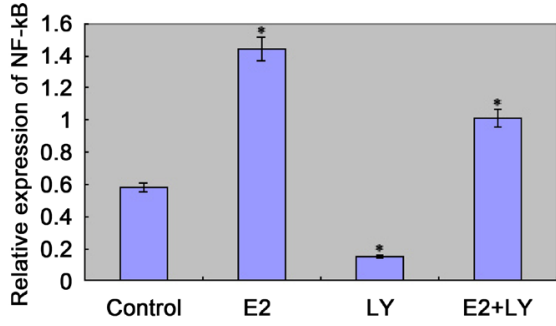

(B)

Figure 4. The effect of estrogen on NF-kB activation. MDA-MB-231 cells were treated with $10^{-8} \mathrm{~mol} / \mathrm{L}$ E2 alone or combination with $2 \mu \mathrm{M}$ lycopene and incubated for $4 \mathrm{~h}$ before the cells harvested for lysis. The signals of NF-kB quantified after measurement of the optical density of the protein bands, and the relative expression of NF-kB is shown in the bar diagram. Data represent a mean of three independent experiments ${ }^{*} p<0.05$. (A) expression of NF-kB in MDA-MB-231 cells treated with E2 alone or combination with lycopene; (B) bar diagram of the relative expression of NF-kB.
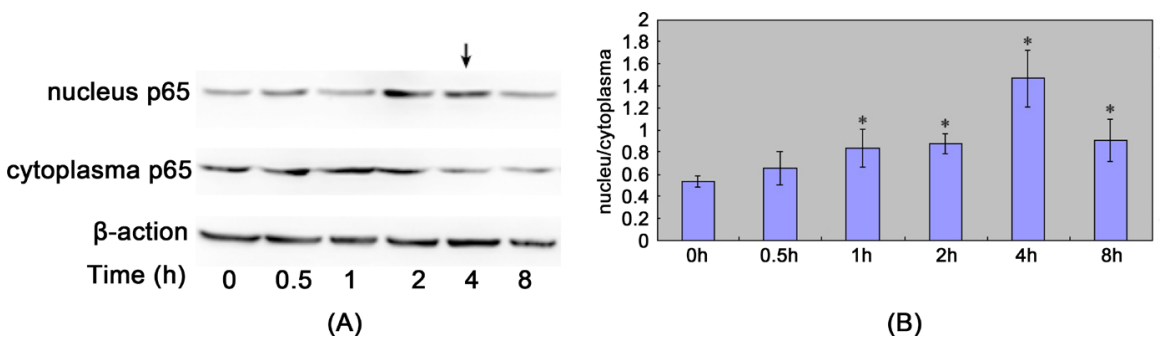

Figure 5. The effect of estrogen on NF-kB nuclear translocation. ${ }^{*} \mathrm{p}<0.05$. (A) expression of NF-kB in nucleus and cytoplasma of MDA-MB-231 cells treated with E2, relative amount of NF-kB in nucleus was increased by estrogen stimulation with time depending and the peak level of NF-kB in nucleus present at $4 \mathrm{~h}$ stimulation (black arrow); (B) bar diagram of the ratio of NF-kB in nucleus and cytoplasma.

of the NF-kB DNA-binding activity; pre-treated with lycopene with $2 \mu \mathrm{M}$ concentration for $4 \mathrm{~h}$, the expression of NF-kB was significantly inhibited and this inhibition was turned over by combination with $\mathrm{E} 2$, the expression level of NF-kB was significantly recovered and even higher than control.

Furthermore, the ratio between the content of NF-kB in nucleus and cytoplasma was used to present the nuclear translocation of NF-kB in MDA-MB-231 cells upon estrogen stimulation. Results showed that before exposure to $10^{-8}$ $\mathrm{mol} / \mathrm{L} \mathrm{E} 2, \mathrm{NF}-\mathrm{kB}$ in nucleus was nearly $65 \%$ of cytoplasma; after activated by $10^{-8} \mathrm{~mol} / \mathrm{L} \mathrm{E} 2, \mathrm{NF}-\mathrm{kB}$ gradually translocated to nucleus according to the exposure time and the peak level of NF-kB in nucleus appeared at $4 \mathrm{~h}$ with almost 1.5 folds amount of NF-kB compared to the cytoplasma (Figure 5).

\subsection{Estrogen Induced IL-8 Production in MDA-MB-231 Cells}

Overexpression of IL-8 has been detected in many human tumors, including breast cancer, and is associated with poor prognosis [29]. We investigated the effect of estrogen on IL-8 production via NF-kB transcription in MDA-MB-231 cells by ELISA. Results showed that the pre-incubation of MDA-MB-231 cells with $10^{-8} \mathrm{~mol} / \mathrm{L}$ E2 for different time length had significant effect on IL-8 pro- 
tein production in culture medium and IL-8 production reached the peak level at $8 \mathrm{~h}$ treatment with estrogen (Figure 6), demonstrating the key role of estrogen in IL-8 production by NF-kB modulation.

\subsection{Estrogen Promoted the Invasion Activities of MDA-MB-231 Cells}

To determine the role of estrogen in breast cancer cells, the metastatic potential of MDA-MB-231 cells was investigated by using in vitro Matrigel invasion assay. Results showed that the invasive potential of MDA-MB-231 cells was significantly promoted by estrogen stimulation and the stimulated cells exhibited 3 folds increase in invasion above control cells (Figure 7). Thus, it seems like estrogen had significant effect on in vitro invasion activities of MDA-MB-231 cells.

\section{Discussion}

Many studies have reported that estrogen-mediated activation of GPER was correlated with many rapid signaling events in cells including activation of EGFR [30], production of cAMP [31] intracellular calcium mobilization [32]

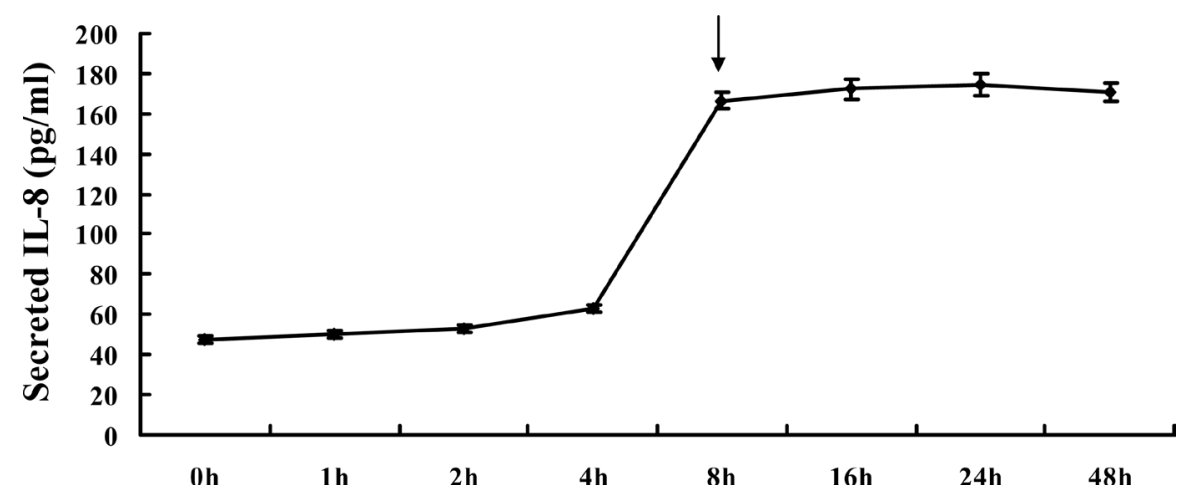

Figure 6. Estrogen induced IL-8 production in MDA-MB-231 cells. MDA-MB-231 cells were treated with $10^{-8} \mathrm{~mol} / \mathrm{L}$ E2 incubated for different time length before the cells culture medium harvested for ELISA. There was no significant increase for IL-8 in culture medium for IL-8 in $4 \mathrm{~h}$ treatment with E2, but the peak level of IL-8 presented at $8 \mathrm{~h}$ treatment.

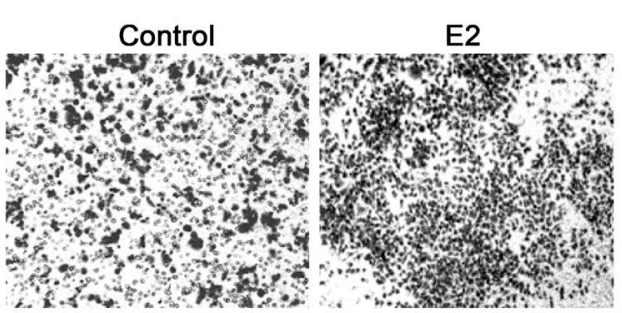

(A)

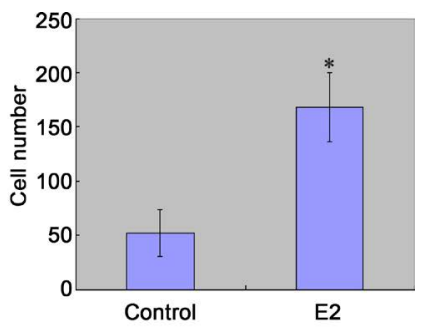

(B)

Figure 7. (A) Dark staining were invaded MDA-MB-231 cells, E2 induced more cells invaded through the Matrigel; (B) The number of invaded MDA-MB-231 cells counted from 5 equally divided zones of the membrane. The E2 stimulated cells exhibited almost 3 folds invasive activities than control cells. Data represent a mean of three independent experiments ${ }^{*} \mathrm{p}<0.05$. 
and PI3K activation [33]. But, how to GPER coordinate with other membrane receptors and involve in transcriptional regulation is still not intensively discussed. In this study, we reported for the first time that the estrogen-mediated GPER stimulation would activate the ERK/Akt signaling pathway and then albeit indirectly, stimulated the activation and nuclei translocation of NF-kB; Autocrine of IL- 8 was promoted by activated NF-kB and the accumulation of IL- 8 may directly activate CXCR1resulting in enhanced invasion activities of breast cancer cells MDA-MB-231.

GPER protein is expressed in $\sim 50 \%$ of all breast cancers, regardless of their ER status [34]. Our studies reinforced that GPER was positive in $68.9 \%$ of our primary breast cancer specimens, although the number of the tissue samples was limited, the results still could indicate the wide distribution for GPER in breast cancers. Besides, the expression of GPER is significantly associated with CXCR1 which is an important chemokine receptor for breast cancer cells proliferation and migration [20]. Our findings showed 96\% of the CXCR $1+$ specimens were positive for GPER. These results may imply some potential signaling chains between these two membrane receptors in breast cancer especially considering the manipulation in IL-8 expression by GPER signaling pathways.

When we compared the expression difference of nuclear estrogen receptor $\mathrm{ER} \alpha, \mathrm{ER} \beta$ and membrane receptor GPER between metastatic breast cancer cell line MDA-MB-231 and non-metastatic breast cancer cell line MCF-7, we found that the GPER expression was significantly independent with ER $\alpha$ and ER $\beta$. Although the relative expression amounts in MCF-7 were 4 folds for ER $\alpha$ and 18 folds for $\mathrm{ER} \beta$ to MDA-MB-231 respectively, the MDA-MB-231 and MCF-7 cells had very similar expression level of GPER and this result is consistent with previous histology findings which referred the GPER expression had no significant relationship with ERs status [35]. Furthermore, our findings showed that the relative expression level of CXCR1 was nearly 3 folds higher in MDA-MB-231 than MCF-7 cells. As two kinds of classical breast cancer cell lines, the metastatic MDA-MB-231 naturally has more invasive activities than non-metastatic MCF-7 despite they have similar expression of GPER, this may indicate that not the GPER but the cross-talk between GPER and CXCR1 would determine the malignity of breast cancer.

Our studies also provided the direct evidences that the activated GPER by estrogen promoted the phosphorylation level of ERK and Akt in MDA-MB-231 cells. Stimulated by $10^{-8} \mathrm{~mol} / \mathrm{L}$ E2, the peak phosphorylation level of ERK and Akt in MDA-MB-231 cells were observed within 5 and 15 mins respectively (Figure 4) and these results were consistent with earlier reports which referred to the non-transcriptional effect GPER in breast cancer cells [8] [9] [10] [11]. In particularly, our findings have also indicated that GPER signaling may trigger a typical gene expression profile which was mainly about NF-kB. NF-kB is one of the redox-sensitive transcription factors. Upon stimulation, activated NF-kB will translocate to the nucleus and bind to promoters of its target genes and regulates 
the expression of genes involved in many cellular events including proliferation and migration through the activation of the Akt and ERK cascades [25] [26] [27] [28]. After treated by estrogen for $4 \mathrm{~h}$, the total expression of NF-kB in MDA-MB-231 cells increased almost 2-fold than control and the nucleus translocation of NF-kB was significantly promoted (Figure 5 , Figure 6). These results together with FOS and AP-1 which were recognized previously as downstream transcriptional factors of GPER will further our understanding on transcriptional effect of GPER in breast cancers. More importantly, when we moved forward to dissect the detailed information on effect of GPER activation on breast cancer cells invasion via transcriptional way, we found the autocrine of IL- 8 was significantly promoted. IL-8 which is reported to play an important role in tumor progression and metastasis [14] is one of the candidates in NF-kB modulation pathways. Our results showed that the pre-incubation of MDA-MB-231 cells with $10^{-8} \mathrm{~mol} / \mathrm{L}$ E2 had significant effect on IL-8 protein production in culture medium and the peak level of IL-8 was observed at $8 \mathrm{~h}$ (Figure 7). As a cytokine of the CXC family, IL-8 will directly activate the membrane receptor CXCR1 which has important effect on breast cancer cells migration and metastasis. In term of the high expression level of CXCR1 in metastatic breast cancer cell line MDA-MB-231, it's reasonable to reach the hypothesis the boosted autocrine of IL-8 mediated by estrogen may promote the invasion of the MDA-MB-231 cells via CXCR1 activation. When we furthered our research to detect the effect of estrogen on breast cancer cell invasive activities, we found after stimulated MDA- MB-231 with estrogen for $8 \mathrm{~h}$, the stimulated cells exhibited 3 folds increase in invasion above control cells (Figure 7) and this result coordinated with the increased production of IL- 8 in culture medium. These results implied estrogen-mediated GPER stimulation may indirectly affect the NF-kB transcriptional events to regulate breast cancer cells invasion and IL-8/CXCR1 may be an important molecular trigger in this pathway.

\section{Conclusion}

In conclusion, our data filled this field that GPER may be an important regulator for invasive activities of breast cancer cells. Despite the effect on triggering rapid signaling pathways, activated GPER by estrogen also could indirectly affect the activation of transcriptional factor NF-kB and then regulate the interaction between IL-8 and CXCR1 and finally boost the invasive activities of the metastatic breast cancer cells. Targeting the GPER/CXCR1 cross-talk may be a potential method for breast cancer therapies.

\section{Acknowledgements}

This study was supported by NNSFC (National Natural Science Foundation of China, No. 31201047 to Jiang), by SRFDP (Research Fund for the Doctoral Program of Higher Education, No. 20125503120018 to Jiang), by the open fund of Key Laboratory of Ministry of Education (No. CQKLBST-2012-005 to Jiang), by 
the Chongqing Yuzhong District Science and technology project (No. 20150115).

\section{References}

[1] Nilsson, S., Makela, S., Treuter, E., Tujague, M., Thomsen, J., Andersson, G., Enmark, E., Pettersson, K., Warner, M. and Gustafsson, J.A. (2001) Mechanisms of Estrogen Action. Physiological Reviews, No. 81, 1535-1565.

[2] Pike, M.C., Pearce, C.L. and Wu, A.H. (2004) Prevention of Cancers of the Breast, Endometrium and Ovary. Oncogene, No. 23, 6379-6391. https://doi.org/10.1038/sj.onc.1207899

[3] Bai, Z. and Gust, R. (2009) Breast Cancer, Estrogen Receptor and Ligands. Archiv der Pharmazie (Weinheim), No. 342, 133-149. https://doi.org/10.1002/ardp.200800174

[4] Zhang, Y.J., Wei, L.H., Wang, J.L. and Sun, T.Z. (2003) Role of Phosphatase PTEN in the Activation of Extracellular Signal-Regulated Kinases Induced by Estradiol in Endometrial Carcinoma Cells. Chinese Medical Journal, 116, 383-387.

[5] Castoria, G., Migliaccio, A., Bilancio, A., Di Domenico, M., de Falco, A., Lombardi, M., Fiorentino, R., Varricchio, L., Barone, M.V. and Auricchio, F. (2001) PI3-Kinase in Concert with Src Promotes the S-Phase Entry of Oestradiol-Stimulated MCF-7 Cells. The EMBO Journal, 20, 6050-6059. https://doi.org/10.1093/emboj/20.21.6050

[6] Kumar, V. and Chambon, P. (1988) The Estrogen Receptor Binds to Its Responsive Element as a Ligand-Induced Homodimer. Cell, 55, 145-156.

https://doi.org/10.1016/0092-8674(88)90017-7

[7] Tsai, S.Y., Tsai, M.J. and O’ Malley, B.W. (1989) Cooperative Binding of Steroid Hormone Receptors Contributes to Transcriptional Synergism at Target Enhancer Elements. Cell, 57, 443-448. https://doi.org/10.1016/0092-8674(89)90919-7

[8] Thomas, P., Pang, Y., Filardo, E.J. and Dong, J. (2005) Identity of an Estrogen Membrane Receptor Coupled to a G Protein in Human Breast Cancer Cells. Endocrinology, 146, 624-632. https://doi.org/10.1210/en.2004-1064

[9] Sirianni, R., Chimento, A., Ruggiero, G., De Luca, A., Lappano, R., Ando, S., et al. (2008) The Novel Estrogen Receptor GPR30 Mediates the Proliferative Effects Induced by 17-ß-Estradiol on Mouse Spermatogonial GC-1 Cell Line. Endocrinology, 149, 5043-5051. https://doi.org/10.1210/en.2007-1593

[10] Prossnitz, E.R. and Maggiolini, M. (2009) Mechanisms of Estrogen Signaling and Gene Expression via GPR30. Molecular and Cellular Endocrinology, 308, 32-38. https://doi.org/10.1016/j.mce.2009.03.026

[11] Maggiolini, M. and Picard, D. (2010) The Unfolding Stories of GPR30, a New Membrane-Bound Estrogen Receptor. Journal of Endocrinology, 204, 105-114. https://doi.org/10.1677/JOE-09-0242

[12] Filardo, E.J., Quinn, J.A., Bland, K.I. and Frackelton Jr., A.R. (2000) Estrogen-Induced Activation of Erk-1 and Erk-2 Requires the G Protein-Coupled Receptor Homolog, GPR30, and Occurs via Transactivation of the Epidermal Growth Factor Receptor through Release of HB-EGF. Molecular Endocrinology, 14, 1649-1660. https://doi.org/10.1210/mend.14.10.0532

[13] Filardo, E.J., Quinn, J.A., Frackelton Jr., A.R. and Bland, K.I. (2002) Estrogen Action via the G Protein Coupled Receptor, GPR30: Stimulation of Adenylyl Cyclase and c-AMP Mediated Attenuation of the Epidermal Growth Factor Receptor-toMAPK Signaling Axis. Molecular Endocrinology, 16, 70-84.

https://doi.org/10.1210/mend.16.1.0758 
[14] Xie, K. (2001) Interleukin-8 and Human Cancer Biology. Cytokine \& Growth Factor Reviews, 12, 375-391. https://doi.org/10.1016/S1359-6101(01)00016-8

[15] Matsuo, Y., Ochi, N., Sawai, H., Yasuda, A., Takahashi, H., Funahashi, H., Takeyama, H., Tong, Z. and Guha, S. (2009) CXCL8/IL-8 and CXCL12/SDF-1alpha CoOperatively Promote Invasiveness and Angiogenesis in Pancreatic Cancer. International Journal of Cancer, 124, 853-861. https://doi.org/10.1002/ijc.24040

[16] Merritt, W.M., Lin, Y.G., Spannuth, W.A., Fletcher, M.S., Kamat, A.A., Han, L.Y., Landen, C.N., Jennings, N., De Geest, K., Langley, R.R., Villares, G., Sanguino, A., Lutgendorf, S.K., Lopez-Berestein, G., Bar-Eli, M.M. and Sood, A.K. (2008) Effect of Interleukin-8 Gene Silencing with Liposome-Encapsulated Small Interfering RNA on Ovarian Cancer Cell Growth. Journal of the National Cancer Institute, 100, 359 372. https://doi.org/10.1093/jnci/djn024

[17] Freund, A., Chauveau, C., Brouillet, J.-P., Lucas, A., Lacroix, M., Licznar, A., Vignon, F. and Lazennec, G. (2003) IL-8 Expression and Its Possible Relationship with Estrogen-Receptor-Negative Status of Breast Cancer Cells. Oncogene, 22, 256-265. https://doi.org/10.1038/sj.onc.1206113

[18] Holmes, W.E., Lee, J., Kuang, W.J., Rice, G.C. and Wood, W.I. (1991) Structure and Functional Expression of a Human Interleukin-8 Receptor. Science, 253, 1278-1280. https://doi.org/10.1126/science.1840701

[19] Murphy, P.M. and Tiffany, H.L. (1991) Cloning of a Complimentary DNA Encoding a Functional Human Interleukin-8 Receptor. Science, 253, 1280-1283. https://doi.org/10.1126/science.1891716

[20] Ginestier, C., Liu, S., Diebel, M.E., Korkaya, H., Luo, M., Brown, M., Wicinski, J., Cabaud, O., Charafe-Jauffret, E., Birnbaum, D., Guan, J.L., Dontu, G. and Wicha, M.S. (2010) CXCR1 Blockade Selectively Targets Human Breast Cancer Stem Cells In Vitro and in Xenografts. The Journal of Clinical Investigation, 120, 485-497. https://doi.org/10.1172/JCI39397

[21] Yoshida, A., Yoshida, S., Khalil, A.K., Ishibashi, T. and Inomata, H. (1998) Role of NF-kappaB-Mediated Interleukin-8 Expression in Intraocular Neovascularization. Investigative Ophthalmology \& Visual Science, 39, 1097-1106.

[22] Elliott, C.L., Allport, V.C., Loudon, J.A., Wu, G.D. and Bennett, P.R. (2001) Nuclear Factor-KappaB Is Essential for Up-Regulation of Interleukin-8 Expression in $\mathrm{Hu}$ man Amnion and Cervical Epithelial Cells. Molecular Human Reproduction, 7, 787-790. https://doi.org/10.1093/molehr/7.8.787

[23] Filardo, E.J., Quinn, J.A., Bland, K.I. and Frackelton Jr., A.R. (2000) Estrogen-Induced Activation of Erk1 and Erk2 Requires the G-Protein-Coupled Receptor Homolog, GPR30, and Occurs via Transactivation of the Epidermal Growth Factor Receptor through Release of HB-EGF. Molecular Endocrinology, 14, 1649-1660. https://doi.org/10.1210/mend.14.10.0532

[24] Bhola, N.E. and Grandis, J.R. (2008) Crosstalk between G-Protein-Coupled Receptors and Epidermal Growth Factor Receptor in Cancer. Frontiers in Bioscience, 13, 1857-1865. https://doi.org/10.2741/2805

[25] Nadel, J.A. (2001) Role of Epidermal Growth Factor Receptor Activation in Regulating Mucin Synthesis. Respiratory Research, 2, 85-89. https://doi.org/10.1186/rr43

[26] O’Donnell, R.A., Richter, A., Ward, J., Angco, G., Mehta, A., et al. (2004) Expression of ErbB Receptors and Mucins in the Airways of Long Term Current Smokers. Thorax, 59, 1032-1040. https://doi.org/10.1136/thx.2004.028043

[27] Shao, M.X., Nakanaga, T. and Nadel, J.A. (2004) Cigarette Smoke Induces MUC5AC 
Mucin Overproduction via Tumor Necrosis Factor-A-Converting Enzyme in $\mathrm{Hu}-$ man Airway Epithelial (NCI-H292) Cells. American Journal of Physiology-Lung Cellular and Molecular Physiology, 287, L420-L427. https://doi.org/10.1152/ajplung.00019.2004

[28] Takeyama, K., Jung, B., Shim, J.J., Burgel, P.R., Dao-Pick, T., et al. (2001) Activation of Epidermal Growth Factor Receptors Is Responsible for Mucin Synthesis Induced by Cigarette Smoke. American Journal of Physiology-Lung Cellular and Molecular Physiology, 280, L165-L172.

[29] Ning, Y., Manegold, P.C., Hong, Y.K., Zhang, W., Pohl, A., Lurje, G., Winder, T., Yang, D., LaBonte, M.J., Wilson, P.M., Ladner, R.D. and Lenz, H.J. (2011) Interleukin-8 Is Associated with Proliferation, Migration, Angiogenesis and Chemosensitivity In Vitro and In Vivo in Colon Cancer Cell Line Models. International Journal of Cancer, 128, 2038-2049. https://doi.org/10.1002/ijc.25562

[30] Filardo, E.J., Quinn, J.A., Bland, K.I. and Frackelton Jr., A.R. (2000) Estrogen-Induced Activation of Erk1 and Erk2 Requires the G-Protein-Coupled Receptor Homolog, GPR30, and Occurs via Transactivation of the Epidermal Growth Factor Receptor through Release of HB-EGF. Molecular Endocrinology, 14, 1649-1660. https://doi.org/10.1210/mend.14.10.0532

[31] Thomas, P., Pang, Y., Filardo, E.J. and Dong, J. (2005) Identity of an Estrogen Membrane Receptor Coupled to a G Protein in Human Breast Cancer Cells. Endocrinology, 146, 624-632. https://doi.org/10.1210/en.2004-1064

[32] Brailoiu, E., et al. (2007) Distribution and Characterization of Estrogen Receptor G-Protein Coupled Receptor 30 in the Rat Central Nervous System. Journal of Endocrinology, 193, 311-321. https://doi.org/10.1677/JOE-07-0017

[33] Revankar, C.M., Cimino, D.F., Sklar, L.A., Arterburn, J.B. and Prossnitz, E.R. (2005) A Transmembrane Intracellular Estrogen Receptor Mediates Rapid Cell Signaling. Science, 307, 1625-1630. https://doi.org/10.1126/science.1106943

[34] Filardo, E.J., et al. (2006) Distribution of GPR30, a Seven Membrane-Spanning Estrogen Receptor, in Primary Breast Cancer and Its Association with Clinicopathologic Determinants of Tumor Progression. Clinical Cancer Research, 12, 63596366. https://doi.org/10.1158/1078-0432.CCR-06-0860

[35] Luo, H.-J., Luo, P., Yang, G.-L., Peng, Q.-L., Liu, M.-R. and Tu, G. (2011) G-Protein Coupled Estrogen Receptor 1 Expression in Primary Breast Cancers and Its Correlation with Clinicopathological Variables. Journal of Breast Cancer, 14, 185-190. https://doi.org/10.4048/jbc.2011.14.3.185 
Submit or recommend next manuscript to SCIRP and we will provide best service for you:

Accepting pre-submission inquiries through Email, Facebook, LinkedIn, Twitter, etc. A wide selection of journals (inclusive of 9 subjects, more than 200 journals)

Providing 24-hour high-quality service

User-friendly online submission system

Fair and swift peer-review system

Efficient typesetting and proofreading procedure

Display of the result of downloads and visits, as well as the number of cited articles Maximum dissemination of your research work

Submit your manuscript at: http://papersubmission.scirp.org/

Or contact jbm@scirp.org 